Instructions for authors, subscriptions and further details:

\title{
Masculinities and Emotional Deficit: Linkages between Masculine Gender Pattern and Lack of Emotional Skills in Men who Mistreat Women in Intimacy
}

Ana Dolores Verdú Delgado ${ }^{1}$

Carmen Mañas Viejo ${ }^{2}$

1) Universidad Técnica Particular de Loja, Equador

2) Universidad de Alicante, Spain

Date of publication: February $21^{\text {st }}, 2017$

Edition period: June 2017 - October 2017

To cite this article: Verdú Delgado, A.D., \& Mañas Viejo, C. (2017). Masculinities and Emotional Deficit: Linkages between Masculine Gender Pattern and Lack of Emotional Skills in Men who Mistreat Women in Intimacy. Masculinities and Social Change,6(2),166-189. doi:

10.17583/MCS.2017.2589

To link this article: http://doi.org/10.17583/MCS.2017.2589

PLEASE SCROLL DOWN FOR ARTICLE

The terms and conditions of use are related to the Open Journal System and to Creative Commons Attribution License (CC-BY). 
MCS - Masculinities and Social ChangeV Vol. 6 No. 2 June 2017

pp. $166-189$

\section{Masculinities and Emotional Deficit: Linkages between Masculine Gender Pattern and Lack of Emotional Skills in Men who Mistreat Women in Intimacy}

Ana Dolores Verdú Delgado

Universidad Técnica Particular de Loja
Carmen Mañas Viejo

Universidad de Alicante

\section{Abstract}

This paper explores violence against women in the context of partner relationships, through testimonies of professionals from Social Services in five towns in the province of Alicante (Spain), and also of the psychologists who participate in the coordination and implementation of two intervention programs for inmate aggressors in Valencia and Alicante (Spain). Our analysis focuses on the linkages between gender and certain emotional deficits in men who mistreat women in intimacy. Among these deficits, we have stressed: lack of sense of responsibility for one's own actions, lack of empathy, cognitive distortions related to a sexist system of values, troubled view of the world and of the relationships with others, and emotional constriction. We suggest that the non-development of basic emotional abilities by these men, while connected with their gender socialization, requires particular attention for the purpose of treatment and prevention of this type of violence. Regarding relationships with gender-based violence, other relevant issues are raised, such as instrumentalization of women and dependence.

Keywords: violence against women, patterns of masculinity, emotional skills, heterosexual couple 


\section{Masculinidades y Déficit Emocional: Relación entre el Patrón de Género} Masculino y el Déficit de Competencias Emocionales en Hombres que Maltratan a Mujeres en la Intimidad

Ana Dolores Verdú Delgado

Universidad Técnica Particular de Loja
Carmen Mañas Viejo

Universidad de Alicante

\section{Resumen}

Este artículo explora la violencia contra las mujeres en el contexto de la relación de pareja a través de los testimonios de profesionales de Servicios Sociales de cinco municipios alicantinos, y también de los psicólogos y psicólogas que participan en la coordinación y ejecución de diversos programas de reeducación de maltratadores en Valencia y Alicante. El análisis se centra en la relación entre el género y ciertos déficits emocionales manifestados en los hombres que maltratan a mujeres en la intimidad. Entre ellos, hemos destacado: falta de sentido de la responsabilidad sobre sus actos, falta de empatía, distorsiones cognitivas a favor de uno mismo, visión conflictiva del mundo y de las relaciones con los demás y represión emocional. Sugerimos que el no desarrollo de capacidades emocionales básicas en estos hombres, siendo un fenómeno relacionado con la socialización de género, requiere especial atención de cara al tratamiento y prevención de este tipo de violencia. En los resultados también adquieren relevancia algunos elementos presentes en las relaciones con maltrato (como la instrumentalización de la mujer o la dependencia).

Palabras clave: violencia contra las mujeres, modelos de masculinidad, habilidades emocionales, pareja heterosexual. 


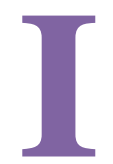

$\mathrm{n}$ the course of history, violence against women (occurring both inside and outside the family circle) has constituted a structural instrument of domination and control over women in patriarchal societies (Alberdi, 2005, p. 17; Amorós, 1990; Bourdieu, 2005). Even today, in a context of constant transformation of gender relations and democracy, violence exerted against the female population is tightly linked to a belief system in which women are not conceived as autonomous human beings, but rather in a subordinate position with respect to men (Alberdi, 2005). For this reason, studies on violence against women from a gender perspective are centered on its structural dimension, linking gender-based violence to social inequalities that affect relationships between men and women (unequal distribution of resources, responsibilities and power) and to the symbolic dominion of masculine over feminine in all cultural spheres (politics, science, education, art, religion, etc.) (Lomas, 2004, 2016; Bourdieu, 2005; Tamayo \& Salazar, 2016). Nevertheless, for some authors (Rodríguez, 2009; Garrido, 2001), the treatment of this violence must not be restricted to its cultural dimension but must take into consideration the psychological particularity that makes some men more inclined than others to exert violence against women in their intimate relationships. Recent studies relate violence to personalities showing low frustration tolerance, paranoid, antisocial and narcissistic features (Garrido, 2001; Rojas, 2005; Mañas, 2005; Amor, Echeburúa, \& Loinaz, 2009) and even a lesser intellectual engagement (Marrs, 2013). These studies argue that the special complexity of gender-based violence in intimacy requires the integration of additional factors likely to have a direct effect on their expression.

Violence against women in intimacy is therefore a multidimensional phenomenon, involving the convergence of sociocultural, interpersonal and intrapsychic aspects (Heise, 1998; Pérez, Fiol, Palmer, Espinosa, \& Guzmán, 2006; Cabrera, 2010; Echeburúa, Amor, Muñoz, Sarasua, \& Zubizarreta, 2017), which needs to be dealt with from interdisciplinary approaches in order to acquire in-depth knowledge of the causes and conditions that produce and uphold it. 


\section{The Construction of Masculinity with Reference to Violence}

Violence against women has been an instrument inherent in patriarchy and, therefore, it has been linked to a cultural model that institutionalizes discrimination against women. Nevertheless, due to its extension, variability and duration non-social sciences have paid it much attention. Within this frame, biological factors intervening in its expression have tended to be overvalued and, many times, justified in terms of human evolutionary history. As opposed to theories defending indirectly a natural origin for violence against women, there have also been abundant studies in different disciplines which regard it as an essentially cultural element. From the perspective of anthropology violence is considered a phenomenon linked to learning rather than to instinct, by virtue of the importance of the symbolic dimension in human behavior. Ashley Montagu (1985) contradicts scientific discourses advocating the immutability and universality of human violence on the basis of a concept of humanity whose particularity is the dependence on culture, and not on instinct, for survival.

Furthermore, going into manifestations of violence against women in depth, psychiatrist Luis Rojas Marcos reminds us that there are always motives acting behind an aggression, thus he denies an innate origin for human violence and stresses that cultural actions determine genetic conditions. "We should remember that people discriminate and dehumanize their fellow men and women for prejudices, they torture for hate, kill for vengeance and rape for domination, not for instinct" (Rojas, 2005, p. 91). Prejudices, hate, vengeance and domination are expressions depending on an ideological system that determine who can exert legitimate violence and who can suffer it, which behavior is appropriate and which one deserves hate and reject, which act is offensive and menacing and what conditions legitimize domination or determine that a group should be dominated.

Within the frame of theories defending a cultural explanation, scientific literature centered on batterers adopts a critical position in relation to traditional masculinity, pointing out its symbolic union with power and the display of success and superiority as a latent aspect behind the expression of violence by the male population (Miedzian, 1995; Subirats, 2007). According to Welzer-Lang (2007), the internalization of a masculine identity associated to a superior position over the feminine one, can 
considerably increase the probabilities of a man exerting some type of violence against a woman in an intimate relationship.

Observing the way in which gender system sexualizes individual expressions of emotions and attitudes, a number of studies show interest in the effects that this kind of masculine socialization has on men's health (Bonino, 2000; Fragoso \& Kashubeck, 2000; Migliaccio, 2014). From this approach, the most common psychopathologies in the male population, and also the high crime rates that it reaches, have a gender interpretation, since they can be related to the internalization of a rigid masculine role. As an example, Bonino provides a classification of "masculine problems" ( $\mathrm{Pm})$. This classification takes into account the different types of distress and pathologies whereby the internalization of the prescribed values of hegemonic masculinity have intervened (Bonino, 2000, pp. 50-58). Amongst these values, he highlights those related to desire for power and authority, self-sufficiency, emotional constriction and indifference towards others and oneself.

The way in which Pm are connected with important emotional deficits suggest a blocked personal development trajectory, coupled with a high level of suffering. Besides, inter-personal relationships under such characteristics lead to "domination behavior" which could easily turn into abuse of power and violence (Bonino, 2000, pp. 50-57). However, all these values tend to be contemplated as positive in androcentric societies, which leads us to rethink the question of violence from the gendered concept of masculinity (Loinaz, Echeburúa, \& Torrubia, 2010; Millana, 2011; Ferrer \& Bosch, 2016). This position allows us to conclude that damages produced by a strictly male-focused socialization process are usually either ignored or, in Luis Bonino's words, easily integrated into a "normalized human model". This, together with historical tendency to place human insanity on the female figure, tends to render masculine "abnormalities" and psychopathologies invisible:

Prevailing subjectivity is mainly governed by the idea that being male means possessing a rational, self-sufficient and defensivecontrolling masculinity which is defined against and to the detriment of the other, within a masculine hierarchy and whereby the woman as subject is a lesser being, which generates a logical 
dichotomy of one or the other, of all or nothing (Bonino, 2000, pp. 42-47).

The survival of this model, in which male identity is inevitably linked to domination and subordination of women, steers other studies towards the belief that present-day violence of men against women is a phenomenon resulting from a traditional masculine identity crisis, influenced by the loss of power over women. Therefore, in a context of change of gender identities, violence can be representative of a self-affirming virility which "appears to be headed at the gesture of the recuperation of lost domination, or, at times, as a purely aggressive reaction to the sense of loss of power over women" (Galende, 2001, p. 74). The prevailing model of masculinity thus represents a mechanism of repression of male subjectivity, subject both to a contradiction between the old gender significance and the new and real possibilities (Galende, 2001), and to a blocking of essential capabilities related to sound personal development (Bonino, 2000). However, these studies do not affirm that masculine violence can be explained by male pathologies. What they suggest is that emotional/psychological problems related to masculine socialization continue to be a fundamental cause of violence exerted by men, especially against women, even in a context of formal equality. In addition, this occurs in a time when patriarchal system is particularly questioned, which can be associated to a worsening of violence against women (Eisler, 2003; Aresti, 2010).

\section{Methodology}

This paper presents some of the results obtained in a research project that forms part of the doctoral thesis produced and co-directed by the authors, within the methodological framework of Social Anthropology and Gender Studies. The general aim of the thesis was to find out the way gender inequality is reflected and reproduced in heterosexual relationships for the purpose of studying the influence of the gender system in aspects like conflict and satisfaction. On the other hand, we wanted to address violence against women in heterosexual relationships by analyzing the interaction of the patriarchal values which shape gender identities and the emotional deficit derived from these values. In this paper, we present data matching this particular aim. 
Violence in this context is interpreted as a strategy of domination, not as a result of a conflict; therefore, we must work with two different samples. This analysis is based on eleven semi-structured interviews with professionals who are experts in gender-based violence and affective relationships. They were, on the one hand, psychologists and social workers from Social Services in the province of Alicante, who work in assisting women who suffer violence by their partners. On the other hand, we interviewed psychologists who participate in the coordination and implementation of two intervention programs for inmate aggressors in Valencia and Alicante (Spain) ${ }^{1}$. These programs treat violence in couple relations by attending not only the intrapsychic characteristics of the man in question, but also the aspects that permit to understand this violence in its socio-historical dimension, thus combining different levels of analysis: intrapersonal, interpersonal, situational and macrosocial ${ }^{2}$. The treatment that these men receive constitutes a substitutive measure of their stay in prison for crimes for which they were found guilty and sentenced for less than two years. The therapy generally takes a cognitive-behavioral approach.

Additionally, concerning professional participation, two types of interviews were conducted: one centered on the analysis of abuse dynamics through the opinions of the abused women's therapists; and the other centered on the study of aspects of professional assessment by the counselors treating condemned men who used violence against their female partners, as well as information on the ensuing treatment.

The hypothesis on which we based to address these conversations was that, in conjunction with cultural elements, emotional dimension plays an important role in the expression of violence against women in the context of intimate partner. In other words,

the units of analysis with which interviews were designed attempted to respond to how the non-development of basic emotional capabilities may interact with a structural gender inequality, producing as a result high probabilities of abuse by the person who wields more power (real or symbolic). 


\section{Discussion on Relevant Aspects in Violence against Women in Intimacy: Conflict and Emotional Deficit}

As already said, gender-based violence has historically constituted an inherent element of patriarchy, being connected to a cultural model that prescribes hierarchical relationships between sexes and legitimates certain levels of violence against women as a way to keep female subordination (Alberdi, 2005, p. 17). Power, and not love between equals, is the most prominent element in a relationship affected by gender-based violence (Moya \& Expósito, 2005; Pérez, Fiol, Guzmán, Palmer, \& Buades, 2008; Pérez \& Fiol, 2013). This fact could be confirmed through the analysis of the origin of the conflicts described by the men and women treated by our informants. In general, situations that trigger a violent response cannot be considered as conflicts derived from the collision of interests and personalities of two different subjects, as it happens in a relationship between equals, but they occur in an attempt to secure domination (Bonino, 2003; Pérez et al., 2006; Bourdieu, 2005). "The habitual cause always has to do with the woman's behavior, by action or omission" (Specialist 2, Social Services).

Relationships described by the experts are constructed upon a sexist ideology that normalizes the lack of recognition of the woman as an autonomous subject with the right to defend her own interests, to the extent that the mere expression of her individuality can justify an explosion of rage by the aggressor. We speak, therefore, of interactions with a high level of instrumentalization and objectification of women, reduced to an object of satisfaction of the man's necessities. In the words of one specialist, "we would say that gender asymmetry is totally internalized; masculine and feminine roles are clearly visible in the relationships they establish, what is expected of a man and what is expected of a woman". The instrumentalization of women may lead men to instill a clearly dysfunctional will to exercise power over women; since, on the one hand, instrumentalization reaffirms men's intolerance by rejecting a free feminine otherness, and on the other hand, it makes them dependent upon using women for protecting their own identity. Therefore, this attitude could be perceived as an expression of the power structure that characterizes the relationship between abuser and abused here studied. The scale of violence 


\section{Verdú \& Mañas - Masculinities and Emotional Deficit}

in this control over the woman, however, may seem invisible in many cases where physical violence is not used ${ }^{3}$.

On the other hand, other of the aspects mentioned in the conversations with experts concerning the approach of these relationships is the prevalence of a concept of love reduced to dependence. In this respect, it is remarkable that the beginning of many of the relationships referred, share rather common characteristics, generally, those of passion and romance, which to the eye of a non-expert are no indicative for a situation leading to gender-based abuse: "The beginning tends to be very romantic, very passionate, there is a lot of sex, they do not think of anything but being together" (Specialist 1, Social Services). Speed and thoughtlessness are also highlighted as general characteristics of the beginning of these relationships. In many cases, indeed, abuse starts with behavior addressed to evade reality in situations of a deeper commitment.

Besides, identification of violence in this context, as well as women's reaction against their attackers, can be especially complex if we observe that, combined with the lack of a universal emotional culture, socialization in romantic love tends to normalize a number of stereotypes that do not facilitate a realistic knowledge about affection and relationship, but they reduce love to dependence. Especially in the imagery of femininity, the interpretation of love influenced by romantic myths can even contain an idea of women's autonomy with negative connotations.

Additionally, the tendency to establish couple relationships of extreme dependence can appear concurrently with a loss of the woman's emotional bonds, which is described by our informants as a man's strategy to weaken his partner's position: "Any relationship that in some way does not lead to his interests, he qualifies it as negative, he gets her to avoid this kind of relationships, and the external circle gets smaller and smaller" (Specialist 3, Social Services).

The abuse of women also presents very particular characteristics concerning the intensity of the emotional bond between perpetrator and victim. Oftentimes it is noted that the pathological emotional dependence experienced by women can be favored by the belief that the man will change if she molds her behavior, or by the influence of love (Garrido, 2001, pp. 156-158), which reinforces the feeling of guilt and responsibility in the woman. "Many of these women stay in the relationship waiting for 
him to change, but it is them who change, because they adapt to that situation in order to survive" (Specialist 2, Social Services). Apart from this fact, experts contemplate other factors that could limit the victim's capacity to break the relationship with her partner, such as: financial aspects, fear, frustration with the necessity of facing the failure of a love project, her own lack of relational skills, or even lack of positive references linked to feminine autonomy.

From the interviews of the psychologists in charge of the batterer intervention programs, we were also able to observe that, even if there is not a concrete profile of inmate aggressors concerning economic status, age or nationality, there is a certain homogeneity in some attitudes or personality traits, coming into line with other studies (Cabrera, 2010; Echeburúa et al., 2017). This condition admits medical treatment ${ }^{4}$ and the development of prevention strategies.

\section{Lack of Sense of Responsibility for One's own Actions}

Lack of responsibility for one's own actions in adulthood can be considered from an emotional intelligence approach a symptom of blocking of personal development (Goleman, 1996). This attitude is expressed by inmate aggressors, possibly associated with two types of phenomena: a) difficulty in establishing limits between what it is and what it is not violence, showing a high level of tolerance towards aggressive actions against women (especially on a psychological level), and b) an apparent ignorance of the effects that their behavior produces on others. Simultaneously, the tendency to intentionally ignore the negative effects of one's own actions on the other can appear as a defense mechanism or self-justification, for the purpose of reducing or avoiding feelings of guilt (Lila, Gracia, \& Herrero, 2012), even if reality must be distorted.

Let's just say that from the moment when defense tactics are used to justify violent behavior, what is actually happening is that reality is being distorted by using the interpretation that makes you feel good. You feel good, even though it's not really the most realistic, the fairest or the most equal interpretation, but you use it, you distort reality in order to find your own well-being (Specialist 6, Batterer Intervention Program). 
At the same time, in conversations with specialists, other factors have been repeatedly stressed, such as a weak development of the capacity for selfcontrol, low frustration tolerance and lack of knowledge of one's own emotions. It seems clear that the majority of men participating in these programs express certain emotional deficits, but also the willingness to impose a particular way of behaving (or being) on their female partners. Those who commit acts of violence in all spheres of life have less presence in these groups.

I would not dare to say that they always do it in a conscious way. I think that many of them don't become aware of the extent of their violence, and that they can even forget some incidents. Indeed, many say «I have not done anything». In many occasions they don't feel guilty. Over time, I do believe that they have consciousness that they exercise power in an asymmetrical relationship (Specialist 8, Battered Intervention Program).

In addition, the feeling of guilt has also connotations of a socio-cultural system which still assigns more responsibility to women for emotional and relationship-related aspects. In these relationships, guilt is firmly placed upon the victim's shoulders, as many of the consulted experts have observed, even up to the point where the woman blames herself for her present situation:

Sometimes she is the one who apologizes. Somehow, she feels she is in charge because the abusive man is delegating responsibility to her. If you don't do it, there will be no trouble, and besides if you apologize, we'll be fine again (Specialist 2, Social Services).

A solid belief in the man's authority, together with a rigid idea of femininity (defined by its duties and obligations), excludes almost any reconsideration of violence by the person exerting it. At the same time, the attitude oriented to the defense of one's own interests and privileges contains an implicit distortion of the other's reality, and most of the time, an evasion of his responsibilities for the care and welfare of others. On the one hand, this tendency is consistent, as already said, with gender socialization. But, on the other hand, it can be reinforced by ideologies 
disseminated by mass media. For instance, when analyzing the relationship between sexist violence and mass media, Eugenia López (2010) states that media play a relevant role in the learning of sexist violence both by modelling (imitation) and by reinforcement (videogames). Lack of rejection of masculine violence by mass media, or even its idealization, can undoubtedly influence the perpetuation of a high rate of gender violence in the Spanish society, where social awareness about the problem has increased and legislation has been developed to address it (Lomas, 2005). In other words, we can think that, if violence continues to have a central role in masculine gender pattern, in some instances, certain levels of violence may be tolerated or even consciously manifested in order to reaffirm a masculine identity.

\section{Lack of Empathy}

Empathy is one of the emotional competencies whose lack is most extended amongst the men participating in intervention programs. Psychologists often relate the serious deficits of empathy of these men to the internalization of a rigid masculine role and to the fact that this lack is expressed selectively, being oriented towards women, in coherence with a gender schema in which the feminine is interpreted as an antagonistic element (Moya \& Expósito, 2005). The lack of empathy, reduced empathy or selective empathy is particularly serious when shown in the intimate sphere, where elements such as support, trust or emotional connection should be firmly in place (Echeburúa \& Fernández, 2009). This is why this aspect is thoroughly explored during therapy by men's counselors.

We work transversally on empathy with the victim (...) he, who's taking on the role of the girl is being insulted, humiliated, (...) they are empathizing enormously then, as they're living out the role, then we change roles and we ask them to try to work it out with a positive outcome, giving them a few guidelines (Specialist 6, Battered Intervention Program).

Nevertheless, for professionals it is difficult to associate this lack to a pathological state. Psychological studies show a tendency to differential expression of empathy on the basis of gender (Mestre, Frías, \& Tur, 1997; 
Retuerto, 2004), linked to cultural influence. Although women are much more predisposed to an affective response based on empathy than men, there are no significant differences between the sexes regarding the cognitive ability that makes easier for human beings to understand the other's situation (Retuerto, 2004). These results suggest that empathy deficit should be analysed with a particular emphasis on value systems and social stereotypes intervening in the construction of masculine and feminine identities. In this respect, some psychologists defend the "Model of Androgyny", according to which, every person, regardless of her/his sex, can adopt characteristics labelled as masculine or feminine. This model gives rise to the "Psychological Androgyny", which breaks correspondence between the biological and psychological elements (Barberá, 2000, p. 45).

Lack of empathy towards women also responds to a process of objectification, necessary for the effective oppression of subordinate groups (Adams, 2010, pp. 66-69). In fact, when we refer to relationships with gender-based violence, we are talking about interactions which are clearly asymmetric, structurally affected by power, and whose dynamic differs from what we consider to be a relationship between equals with conflicts derived from the collision of interests and personalities of two different subjects. In these relationships, the exercise of a woman's freedom, her individual needs or wishes are expressed in a tense climate produced by the need of control over the woman by the man.

\section{Cognitive Distortions Related to a Sexist System of Values}

A large part of the therapy aimed at male aggressors is based on the deconstruction of stereotypes, myths and false beliefs that represent woman as an exploitable and problematic subject, intellectually inferior or different. This means that the cognitive distortions that these men present tend to be closely connected to the sexist gender schema according to which they interpret and give meaning to their relationship. This logic implies, in most cases, an extremely stereotyped view of femininity that assigns to women qualities such as submission, compassion towards men and disposition to personal sacrifice in benefit of others (Pérez et al., 2006; Bonino, 2003; Garrido, 2001). Prejudices related to women's sexuality are also relevant. Most of the sexist insults by these men are sexually connoted. 
They say that women now want to be above men; many of them had problems because their wives met her friends. It's about women's freedom... The fact that women work is perceived as normal, but if they go out for drinks, they are acting like bitches. Stereotypes are there (Specialist 5, Battered Intervention Program).

Given that this schema has been internalized in the men's process of socialization, we must point out the importance of working on the cultural aspect, for it constitutes a context that still produces and reproduces sexist beliefs. In fact, a great part of the assistance received by these men is based on the deconstruction of stereotypes, myths and false beliefs that define the image of women as exploitable and troubled subjects, intellectually inferior or different, to the extent that a natural experience of empathy towards them would be blocked. Again, it is necessary to pay attention to a culture that may be normalizing certain cognitive distortions of reality. Very often, the prevailing values of the collective imagery of gender and sexuality (reduction of women to sexual objects, concealment of the affective dimension in men's life, sexualization of care and power, etc.) are not accurate representations of real interactions between men and women.

Some studies point out the close connection between reification of women and normalization of violence in heterosexual relationships. According to Mercedes Bengoechea, reification of women is a cultural practice that prepares human beings on the cognitive and symbolic level to naturalize violence, since it encapsulates women as victims (Bengoechea, 2006, p. 38), as objects which can be interchanged, possessed, exhibited, used, abused or thrown away (2006, p. 30).

\section{Troubled view of the world and of relationships with others}

It is also common to detect a hostile and defensive relational norm of behavior in this group of men. Frequently, the male aggressor states that he himself feels humiliated and abused by his partner, in spite of the absence of such a fact. This phenomenon is due to the same egocentric feeling whereby he would be unable to judge an action in itself for what it is, but for how it makes him feel. Vicente Garrido also relates the abuser's tendency to victimization and to a wish to evade responsibilities and 
maintain the privileged position given by power. "The male abuser usually feels that he is living in a hostile world, where he is not given the recognition that he deserves" (2001, pp. 158-159).

This attitude also reveals a rigid and warlike vision of relationships, determined by a dichotomist logic that represents one's victory as the other's loss. Bonino points out that masculine subjectivity is currently based on two gender ideologies: individualism, according to which a man must make his will prevail and defend his own interests; and the "demonization/elimination of the Other" (Bonino, 2000, p. 46). In consonance with this thought, traditional and historical models of masculinity are related to a "heroic aggressiveness" that authenticates the practice of violence, gives positive consideration to values such as hierarchy or superiority, and normalizes the dichotomy "I versus the Other", "Everything versus Nothing" and "Winning versus Losing" (2000, p. 46). According to Oscar Guasch, masculinity should be regarded as an "element of social structure that facilitates social control through gender rules" (2008, p. 49). These gender rules are defined by an implicit union of masculine identity with sexism, misogyny, aggressiveness and homophobia. This aspect is consistent with a search for superiority through inferiorization of the other person. Moore and Gillete offer a different interpretation of the devaluation of difference typical of patriarchy. They assert that the true essence of sexist organization lies on fear and rejection of maturity, shown by teen-agers towards women and mature men. Therefore, patriarchy is really "puerarchy" (1993, p. 157), because it reflects an impulse of power in consonance with a child psychology (dominated by an egocentric feeling) that attacks full masculinity and social development, since it is based on child logics. From this approach, the ideological construction of masculine superiority rests upon the wish to hide the child's true vulnerability. As other theories propose, beneath patriarchy lies a combative reaction against difference, built on the construction of symbolic and political systems of domination (Moore \& Gillete, 1993; Reardon, 1985).

In order to modify this problematization of the relationship with the Other, educators resort to the transmission of abilities for conflict resolution, together with an exercise of deconstruction of a masculinity which makes self-esteem dependent on power ${ }^{5}$. The techniques used to 
attain this, usually involve overcoming a vision of personal success which is detrimental to the other. The solution for this problem requires the negotiation and comprehension of another person's feelings and interests.

\section{Emotional constriction}

Emotional constriction is another aspect that affects male aggressors in a general way, having an influence on the process of accumulation of tension integrated in the "cycle of violence" (accumulation of tension - violent outburst - honeymoon) (Lisak, Hopper, \& Song, 1996; Sanmartín, Molina, \& García, 2003, p. 15) and its relation to a gender schema where emotions have feminine connotations. Studies on masculinity focus primarily on the cultural aspect, as the masculine socialization process demands boys the effort to repress feelings and emotions. We can consider that the constriction of feelings, such as vulnerability, tenderness or concern about the other, can lead to a chronic state of tension and unrest, due to the central role played by these aspects in human nature and, in particular, in the experience of love. Rodríguez Luna affirms that this reduced capacity to recognize, express and manage feelings and emotions in men is in fact a determining factor in gender-based violence cases (2009, p. 337).

They consider themselves as men, strong... Men are not supposed to cry and are supposed to dress in blue, and of course they live up to this prototype and function as such. It's difficult for them to be the man who's used to wearing jeans and his John Wayne hat, and suddenly take it off to have a good cry - it's hard for them and when they do, I suppose that they feel relieved, but as I say they're not used to it (Specialist 8, Battered Intervention Program).

The lack of emotional skills relies indeed on a masculinity integrated into a sexist model which encourages failure to face up to responsibility as far as relationships are concerned. However, the emotional constriction characteristic of these men often contains a nuance that turns it into a particularly complex aspect. It is indeed evident that emotional nonimplication in men who abuse is coherent with their denial of intimacy to their partners. Thus, it creates an artificial emotional distance that can be 


\section{Verdú \& Mañas - Masculinities and Emotional Deficit}

considered simultaneously as an act of abuse, and as a way of denying their own need and dependency on the woman (Bonino, 1995; Garrido, 2001).

\section{Conclusion}

As the present-day feminist theory points out, gender-based violence cannot be eradicated without a breakdown of the ideological structure that supports it. This structure, integrated in the traditional gender system, reinforces the idea of legitimate male authority and, at the same time, provides an image of femininity defined by its social duties and obligations, which in turn perpetuates the privilege of power of men over women.

On the other hand, although masculine violence against women has served to maintain the subordination of the feminine population throughout history, current social conditions suggest the need to raise this violence beyond its instrumentality. In a context of formal equality and a certain heterogeneity of values, we can observe that, even if the violence men exert against their female partners responds to an intent of domination, this strategy is not always successful. On numerous occasions, using force in intimacy leads to the breakup of the relationship by the woman, the reporting of the man, social rejection and loss of power.

In this paper, we have focused on some aspects that frequently appear in intimate relationships with gender-based violence, with the intention of understanding this phenomenon by the articulation of cultural and psychological elements. In the first place, we wanted to underline the way in which gender significances determine a dynamic that denies women the condition of autonomous subjects, causing a display of conflict that actually conceals an attempt to subjugate them. We have also paid attention to a possible influence of the romantic model of love that equals the couple's relationship to dependence and normalizes women's subordination by interacting with the gender system.

In the second place, we have connected masculine violence with a social structure in which the idea of masculinity is shaped through superiority, especially over women, and we have placed specific emphasis on the lack of emotional education as an aspect linked to a rigid masculine role. In this respect, we have stressed some of the aspects dealt with by the psychologists and social workers in charge of two intervention programs for 
inmate aggressor. As we were able to observe in the therapies targeted to men sentenced for having exerted violence against women in intimacy, most of them have not developed in their process of socialization abilities considered basic for establishing positive relationships in their social environment. Among these deficits and traits derived from a poor emotional development, in this analysis we have detected: lack of sense of responsibility for one's own actions, lack of empathy, cognitive distortions related to a sexist system of values, a troubled view of the world and of the relationships with others, and emotional constriction.

In other words, in conjunction with cultural elements, emotional dimension plays an important role in the expression of violence against women in the context of intimate relationship. To recognize the cultural basis of this type of violence should not prevent detection of the psychological problems that affect men who exert violence. Ultimately, the non-development of basic emotional abilities by these men, while being connected with the gender system, requires particular attention for the purpose of treatment and prevention of this type of violence.

In the same vein as Vicente Garrido, we think it is worth emphasizing that violence exerted by men against women within couple relationships, far from being a mysterious phenomenon, constitutes a predictable form of violence that can be linked to a patriarchal cultural system. Consequently, it is possible to detect traits expressed by some men to a larger extent than others. Violence against women is not an isolated fact, but a process full of previous signs or events that allow us to predict its outcome (Garrido, 2001, p. 222). The fact that societies are still kept unaware of the real causes of gender violence facilitates its perpetuation, preventing women in danger from defending themselves and naturalizing in men all the sexist and dysfunctional behaviors encompassed in women abuse.

\section{Acknowledgement}

We would like to show our special gratitude to Diane Grafton and Carmen Sánchez Mañas for their great help with the translation and valuable comments. 


\section{Notes}

${ }^{1}$ Specifically, we thank the participation of the professionals of the CONTEXTO Program (Intervention Program for Men Condemned for Violence against Women in the Valencia Province) and the program conducted by the Provincial Courts of Alicante. Both programs follow the criteria established by the Spanish Constitutional Law 1/2004 of 28th December on Comprehensive Protection Measures against Gender Violence. Interviews were conducted in 2010.

${ }^{2}$ This typology corresponds with Bronfenbrenner's Ecological Model (1979).

${ }^{3}$ The relationships referred to by our informants are generally physically violent. However, they explain that physical violence against women within a partner relationship usually begins after a prolonged process of psychological intimidation. Psychological violence is regarded as a subtle, although not less dangerous, violence. It is aimed to the psychic destruction of the individual against whom it is exerted. Psychological harm inflicted on women acts as a warning bell of possible abuse in the health field.

${ }^{4}$ Nevertheless, the success or failure of these strategies will not depend only on the ability of the therapists to put this into practice, but also on the specific conditions of each individual to whom they are addressed, either age, family history, the personal attitude or the level of violence already reached.

${ }^{5}$ Ferrer and Bosch (2016) also stress the deconstruction of masculinity as an essential tool for abusers' rehabilitation.

\section{References}

Adams, C. J. (2010). The rape of animal, the butchering of women. The sexual politics of meat (20th Anniversary Edition). In C. J. Adams (Eds.) A feminist-vegetarian critical theory (pp. 64-91). London y New York: Continuum.

Alberdi, I. (2005). Cómo reconocer y cómo erradicar la violencia contra las mujeres. In I. Alberdi \& L. Rojas (Eds.), Violencia: Tolerancia cero (pp. 10-87). Barcelona: Fundación "La Caixa".

Amor, P. J., Echeburúa, E., \& Loinaz, I. (2009). ¿Se puede establecer una clasificación tipológica de los hombres violentos contra su pareja. International Journal of Clinical and Health Psychology, 3(9), 519539. Retrieved from http://www.aepc.es/ijchp/articulos_pdf/ijchp336.pdf 
Amorós, C. (1990). Violencia contra las mujeres y pactos patriarcales. In V. Maqueira y C. Sánchez (Comps.), Violencia y sociedad patriarcal (pp.1-15) Madrid: Pablo Iglesias.

Aresti, N. (2010). Masculinidades en tela de juicio. Madrid: Cátedra. Barberá, E. (2000). Psicologia i gènere. La perspectiva de género en la disciplina psicológica. In E. Bosch, V. Ferrer \& T. Riera (Comps.), Una ciencia no androcéntrica (pp. 41-62). Palma: Universitat de les Illes Balears.

Bengoechea, M. (2006). «Rompo tus miembros uno a uno» (Pablo Neruda).

De la reificación a la destrucción en los discursos masculinos sobre la mujer. Cuadernos de trabajo social, 19, 25-41. doi:10.5209/CUTS.8406

Bonino, L. (1995). Los micromachismos en la vida conyugal. In J. Corsi (Ed.), Violencia masculina en la pareja (pp.191-208). Buenos Aires: Paidós.

Bonino, L. (2000). Varones, género y salud mental: Reconstruyendo la «normalidad» masculina. In M. Segarra \& A. Carabí, A. (Eds.), Nuevas masculinidades (pp. 41-64) Barcelona: Icaria.

Bonino, L. (2003). Masculinidad hegemónica e identidad masculina. Dossiers feministes, 6, 7-36. Retrieved from http://www.erevistes.uji.es/index.php/dossiers/article/view/735/635

Bourdieu, P. (2005). La dominación masculina revistada. Archipiélago:

Cuadernos de crítica de la cultura, 67, 9-22. Retrieved from https://dialnet.unirioja.es/servlet/articulo?codigo $=1307751$

Cabrera Espinosa, M. (2010). Acercándonos al hombre que ejerce la violencia de género: clasificación y descripción de un grupo de maltratadores. Nómadas, 25(1), 243-265. Retrieved from http://pendientedemigracion.ucm.es/info/nomadas/25/manuelcabrera. pdf

Echeburúa, E., Amor, P. J., Muñoz, J. M., Sarasua, B., \& Zubizarreta, I. (2017). Escala de Gravedad de Síntomas del Trastorno de Estrés Postraumático según el DSM-5: versión forense (EGS-F). Anuario de Psicología Jurídica (2017), 1-11. DOI: 10.1016/j.apj.2017.02.005

Echeburúa, E., \& Fernández Montalvo, J. (2009). Evaluación de un programa de tratamiento en prisión de hombres condenados por violencia grave contra la pareja. International Journal of Clinical 
and Health Psychology, 1, 5-20. Retrieved from http://www.aepc.es/ijchp/articulos_pdf/ijchp-306.pdf

Eisler, R. (2003). El cáliz y la espada. Nuestra historia, nuestro futuro. Santiago de Chile: Editorial Cuatro Vientos.

Ferrer, V. A., \& Bosch, E. (2016). Las masculinidades y los programas de intervención para maltratadores en casos de violencia de género en España.. Masculinities and Social Change, 5(1),28-51. DOI: 10.17583/MCS.2016.1827

Fragoso, J. M., \& Kashubeck, S. (2000). Machismo, gender role conflict, and mental health in Mexican American men. Psychology of Men \& Masculinity, 1(2), 87-97. DOI: 10.1037/1524-9220.1.2.87

Galende, E. (2001). Sexo y amor. Anhelos e incertidumbres de la intimidad actual. Buenos Aires: Paidós.

Garrido, V. (2001). Amores que matan. Acoso y violencia contra las mujeres. Valencia: Algar.

Goleman, D. (1996). La inteligencia emocional. Buenos Aires Javier: Vergara.

Guasch, O. (2008). Género, masculinidad y edad. In A. Téllez \& J. Martínez (Coords.), Investigaciones antropológicas sobre género: de miradas y enfoques (pp. 43-54). Universidad Miguel Hernández de Elche.

Heise, L. (1998). Violence Against Women: An Integrated Ecological Framework. Violence Against Women, 4(3), 262-290. DOI:

10.1177/1077801298004003002

Lisak, D., Hopper, J., \& Song, P. (1996). Factors in the cycle of violence: Gender rigidity and emotional constriction. Journal of Traumatic Stress, 9(4), 721-743. DOI: 10.1007/BF02104099

Lila, M., Gracia, E., \& Herrero, J. (2012). Asunción de responsabilidad en hombres maltratadores: influencia de la autoestima, la personalidad narcisista y la personalidad antisocial. Revista Latinoamericana de Psicología, 44(2), 99-108. Retrieved from http://www.scielo.org.co/scielo.php?pid=S0120$05342012000200009 \&$ script $=$ sci_abstract\&tlng=es

Loinaz, I., Echeburúa, E., \& Torrubia, R. (2010). Tipología de agresores contra la pareja en prisión. Psicothema, 22(1), 106-111. Retrieved from http://www.psicothema.com/pdf/3703.pdf 
Lomas, C. (2004). Los chicos también lloran: identidades masculinas, igualdad entre los sexos y coeducación. Barcelona: Paidós Ibérica.

Lomas, C. (2005). ¿El otoño del patriarcado? El aprendizaje de la masculinidad y de la feminidad en la cultura de masas y la igualdad entre hombres y mujeres. Cuadernos de Trabajo Social, 18, 259-278. DOI: $10.5209 /$ CUTS.8442

Lomas, C. (2016). Lo lingüístico es político. Cuadernos de pedagogía, 465, 56-61. Retrieved from http://www.cuadernosdepedagogia.com/Content/Inicio.aspx

López, E. (2010). Sexismo, violencia y juegos electrónicos. In A. de la Concha (Coord.), El sustrato cultural de la violencia de género. Literatura, arte, cine y videojuegos (pp. 277-320). Madrid: Síntesis.

Mañas, C. (2005). El maltrato hacia la mujer: interiorización de la desigualdad. In C. Mañas \& N. Montesinos (Eds.), Maltrato hacia las mujeres: implicaciones de la desigualdad (pp. 45-68). Centro de Estudios sobre la Mujer, Universidad de Alicante.

Marrs, H. (2013). Conformity to Masculine Norms and Intellectual Engagement. Masculinities \& Social Change, 2(3), 226-244. DOI: 10.4471/mcs.2013.33

Mestre, V., Frías, M. D., \& Tur, A. M. (1997). Variables personales y empatía. In V. Mestre \& E. Pérez-Delgado (Eds.), Cognición y afecto en el desarrollo moral. Evaluación y programas de intervención (pp. 163-193). Valencia: Promolibro.

Miedzian, M. (1995). Chicos son, hombres serán. Cómo romper los lazos entre masculinidad y violencia. Madrid: Horas y HORAS.

Migliaccio, T. (2014). Typologies of men's friendships: constructing masculinity through them. Masculinities \& Social Change, 3(2), 119147. DOI: $10.4471 / \mathrm{mcs} .2014 .47$

Millana, L. (2011). Intervention Programs for Spanish Inmate Aggressors Convicted of Domestic Violence, The Open Criminology Journal, 4, 91-101. DOI: 10.2174/1874917801104010091

Montagu, A. (1985). La naturaleza de la agresividad humana. Madrid: Alianza.

Moore, R., \& Gillete, D. (1993). La nueva masculinidad. Barcelona: Ediciones Paidós Ibérica. 
Moya, M., \& Expósito, F. (2005). Violencia de género. In F. Expósito \& M. Moya (Coords.), Aplicando la psicología social (pp. 201-228). Madrid: Ediciones Pirámide.

Pérez, V. A. F., Fiol, E. B., Palmer, M. C. R., Espinosa, G. T., \& Guzmán, C. N. (2006). La violencia contra las mujeres en la pareja: creencias y actitudes en estudiantes universitarios/as. Psicothema, 18(3), 359366. Retrieved from

http://www.unioviedo.net/reunido/index.php/PST/article/download/8 442/8306

Pérez, V. A. F., Fiol, E. B., Guzmán, C. N., Palmer, M. C. R., \& Buades, E. G. (2008). El concepto de amor en España. Psicothema, 20(4), 589595. Retrieved from

http://www.unioviedo.net/reunido/index.php/PST/article/download/8 $702 / 8566$

Pérez, V. F., \& Fiol, E. B. (2013). Del amor romántico a la violencia de género. Para una coeducación emocional en la agenda educativa. Profesorado, Revista de Currículum y Formación del Profesorado, 17(1), 105-122. Retrieved from http://www.ugr.es/ recfpro/rev171ART7.pdf

Reardon, B. A. (1996). Sexism and the World System. New York: Syracuse University Press.

Retuerto, A. (2004). Diferencias en empatía en función de las variables género y edad. Apuntes de Psicología, 22(3), 323-339. Retrieved from http://copao.cop.es/files/contenidos/VOL22_3_3.pdf

Rodríguez Luna, R. (2009). La responsabilidad masculina por la violencia contra la (ex) pareja. In G. Creazzo \& L. Bianchi (Eds.), $E l$ desarrollo de estrategias de trabajo con hombres que usan la violencia contra las mujeres en sus relaciones intimas (pp. 328-350). Barcelona: ITD. Programa Daphne II.

Rojas, L. (2005). Semillas y antídotos de la violencia en la intimidad. In I. Alberdi \& L. Rojas, Violencia: Tolerancia cero (pp. 90-125). Barcelona: Fundación "La Caixa".

Tamayo, J. J., \& Salazar, O. (2016). La superación feminista de las masculinidades sagradas. Atlánticas, (1), 213-239. DOI:

10.17979/arief.2016.1.1.1396 
Sanmartín, J., Molina, A., \& García, Y. (Eds.) (2003). Informe

Internacional 2003. Violencia contra la mujer en las relaciones de pareja. Estadísticas y legislación. Valencia: Centro Reina Sofía para el Estudio de la Violencia.

Subirats, M. (2007). Ser hombre. In M. Castells \& M. Subirats, Mujeres y hombres. ¿Un amor imposible? (pp. 49-135). Madrid: Alianza Editorial.

Welzer-Lang, D. (2007). La violencia doméstica a través de 60 preguntas y 59 respuestas. Madrid: Alianza Editorial.

Ana Dolores Verdú is fulltime profesor and researcher at the Universidad Técnica Particular de Loja, Ecuador.

Carmen Mañas Viejo is associate professor at the Universidad de Alicante, Spain

Contact Address: Direct correspondence to Carmen Mañas Viejo, Departamento de Psicología Evolutivay Didáctica. Carretera de San Vicente del Raspeig s/n 03690 San Vicente del Raspeig, Alicante (Spain),email: carmen.mavi@ua.es 